\title{
Angiotensin-converting enzyme gene polymorphism in patients with Essential hypertension
}

\author{
Magda I.M. El-Mahdy and Mona M. Morsy* \\ Clinical pathology and Internal Medicine* Departments, Faculty of Medicine for \\ Girls. Al Azhar University
}

\begin{abstract}
:
\end{abstract}
Several genetic investigations have been attempted to elucidate the association of angiotensin-converting enzyme (ACE) gene polymorphism and essential hypertension. This study was conducted to investigate the frequency of ACE gene insertion/deletion (I/D) polymorphism in patients with essential hypertension (EH). The study included one hundred patients with essential hypertension and seventy age and sex matched healthy individuals as a control group. The patients and control group were subjected to routine investigations, assay of serum cholesterol, triglycerides, high density lipoprotein-cholesterol (HDL-C), low density lipoprotein-cholesterol (LDL-C) and assay of ACE gene I/D polymorphism using real-time polymerase chain reaction (PCR). The results of the study showed that the frequency of DD,ID and II genotypes were $42 \%, 44 \%$ and $14 \%$ respectively in hypertensive group and 30\%, 50\% and $14 \%$ respectively in control group with significantly higher frequency of DD genotype in patients as compared to the control group $(p<0.05)$. There was a significant association between DD genotype and hypertension, as there was significant increase in both systolic and diastolic blood pressure in patients with DD genotype as compared to other genotypes. Serum cholesterol, HDL-C and LDL $-\mathrm{C}$ levels showed significant increase in patients as compared to the control group $(\mathrm{P}<0.001, \mathrm{P}<0.001$ and $\mathrm{P}<0.001$ : respectively ) Also, serum Cholesterol and LDL-C levels showed significant increase in patients with DD and ID genotypes as compared to II genotype, while triglycerides and HDL-C didn't show differences between the three genotypes. It was concluded that the DD genotype of ACE gene showed significantly higher frequency among patients with essential hypertension as compared to the normal subjects and that DD genotype was associated with significantly higher blood pressure as compared to ID and II genotypes. Also, DD genotype was associated with significantly higher serum cholesterol and LDL-C as compared to II genotype. This polymorphism in the ACE gene may contribute to the pathogenesis and severity of essential hypertension and may help in selection of anti-hypertensive drugs.

\section{Introduction:}

Hypertension is a common risk factor for coronary artery and cerebrovascular diseases that are the major causes of morbidity and mortality, accounting for more than 12 million deaths annually worldwild
(Caulfield et al., 2002). Essential hypertension is a multifactorial trait involving interactions among genetic, environmental and demographic factors (Kato,2002). Several genetic investiga tions have been attempted to elucidate 
the genetic pathogenesis of essential hypertension. However, ident -ification of individual genes contrib. -uting to common essential hypertension has proved more difficult (Lifton et al., 2001). Most of these genes are, directly or indirectly, coupled to salt handling of kidney, being included in renninan giotensin system, steroid hormone metabolism and renal sodium transp orters (Matsubara , 2000). Blood pressure regulation involves different vasopressor systems: sympathetic, rennin-angiotensin and vasopressin systems (Lasocki et al., 2002). The human angiotensin-converting enzyme gene, located on chromosome 17 cont ains a length polymorphism consisting of the presence (insrtion, I) or absence ( deletion , D) of a 287 base pair DNA domain in the interon 16, resulting in three genotypes: DD and II, homoz ygotes and ID heterozygotes (Montgomery et al., 2002). ACE is a zink-metallopeptidase that converts angiotensin I to the potent vasoconst rictor angiotensin II and that degrades bradykinin, a powerfull vasodilator , both for regulation of vascular tone and cardiac functions (Baudin, 2002).

Aim of the work: The aim of this study is the analysis of ACE gene polymorphism in patients with essential hypertension and to determine the association of genetic variants with blood pressure and plasma lipids.

\section{Subjects and methods :}

The present study included 100 patients with essential hypertension( 46 males and 54 females, aging 35 to 55 years old) and 70 apparently healthy individuals (32 males and 38 females, aging 35 to 56 years old) as a control group. They were selected from Internal Medicine Department in AL Zahraa University Hospital. Subjects were classified as having essential hyperte - nsion if they have systolic blood pressure $\geq 140 \mathrm{~mm} \mathrm{Hg}$ and /or diastolic blood pressure $\geq 90 \mathrm{~mm} \mathrm{Hg}$ on at least two separate occasions; and age of onset less than 65 (Tamaki et al., 2002). The patients and control group were subjected to the following:

History taking, full clinical examination and measurement of blood pressure( 2 measurements, on 2 occasi ons separated by an interval of 4 weeks), abdominal ultrasonography and electrocardiography.

Withdrawal of $5 \mathrm{ml}$ of venous blood, $2 \mathrm{ml}$ were anticoagulated with EDTA for extraction of DNA using Capture Column kit (Centra Systems, USA) and $3 \mathrm{ml}$ were left to clot and sera were separated for assay of:

1. Routin laboratory investigations( fasting and postprandial blood glucose, blood urea, serum creati nine, ALT, AST and serum alkaline phosphatase, using Hitachi 911 chemistry auto analyzer and kits of Roche).

2. Serum cholesterol, triglycerides, high density lipoprotein -cholesterol (HDL-C) and low density lipopr otein - cholesterol (LDL-C), using Hitachi 911 chemistry auto analyzer and kits of Roche.

Patients with diabetes mellitus, renal disease, hepatic diseases, known secondary hypertension or ischaemic heart disease were exclu ded from the study. Also, patients on oral contraceptives or corticoste roids, were excluded from the study.

3. Assay of angiotensin-converting enzyme gene polymorphism: by real-time PCR, using Light Cycler system and reaction mix, DNA master SYBR Green I (Roche Diagnostics). Light Cycler is a rapid thermocycler with online fluoresc ence detection, in which the PCR is 
carried out in glass capillaries. Heating and cooling are by temperature-controlled airflow. The capillaries are placed in a rotationsymmetric chamber to ensure homogeneous temperature distribu tion (Wilhelm et al.,2000). PCR was performed in disposable capillaries. The reaction volume was $20 \mu \mathrm{l}$, containing: $5 \mu \mathrm{l}$ of extracted DNA, $0.2 \mu \mathrm{M}$ of each primer reported by Rigat et al.,(1992) (forward primer, 5-CTGGAGACCACTCCCATCC TTCT -3 and reverse primer 5GATGTGGCCAACATTCGTCAG AT-3 ), $10 \mu \mathrm{l}$ of SYBR Green I master mix ( $0.2 \mathrm{mmol}$ dTNP, 0.5 $\mathrm{U}$ Taq DNA polymerase and $1 \mathrm{x}$ PCR buffer and $4 \mathrm{mM} \mathrm{MgCl}_{2}$ ) and $5 \mathrm{ml} \mathrm{H} 2 \mathrm{O}$ SYBR Green I is a DNA double-stranded specific fluorescent dye. It binds to the amplified PCR products and the amplicon can be detected by its fluorescence.

The PCR amplification protocol consisted of :initial denaturation at $95^{\circ} \mathrm{C}$ for 2 minutes, followed by 40 amplif ication cycles at $95^{\circ} \mathrm{C}$ (temperature ramp was constant at $20^{\circ} \mathrm{C} / \mathrm{s}$ ), annealing at $58^{\circ} \mathrm{C}$ for 10 seconds, and extension at $72^{\circ} \mathrm{C}$ for 20 seconds. Fluorescence was measured at the end of the extension phase. After amplify cation was completed a melting curve analysis was performed by cooling the reaction to $60^{\circ} \mathrm{C}$ then heating to $95^{\circ} \mathrm{C}$. The fluorescence signal (F) was monitored continuously during temper ature ramp and then plotted against the temperature( $\mathrm{T})$. These curves were then converted to melting peaks by plotting the negative derivative of the fluorescence with respect to temperature against temperature (-dFl-dT versus $\mathrm{T}$ ). Two melting peaks at $85.5{ }^{\circ} \mathrm{C}$ and 89 ${ }^{\circ} \mathrm{C}$ corresponding to I and D alleles were formed ( figure 1). To ensure that the correct product was amplified in the reaction, all samples were separated by ethidium bromide stained $2 \%$ agarose gel electrophoresis and expected prod ucts of 490 (I allele) and / or 190 ( D allele) bp (figure 2 ) were visualized by ultraviolet transilluminator (Lin et al., 2001).

\section{Statistical analysis:}

The data were analyzed using Statistical Package for Social Science (SPSS 8 for windows) and expressed as mean \pm SD. Student $t$ test was used for comparing means .Chi-square test was used for testing proportions indepen dence. $\mathrm{p}$ value less than 0.05 was considered significant .

\section{Results:}

The results of systolic and diastolic blood pressure, serum cholesterol, HDL-C and LDL-C, showed significant increase in hypert ensive patients as compared to the control group, while serum triglycerides showed non significant changes ( table 1). The frequencies of DD, ID and II genotypes were $42 \%, 44 \%$ and $14 \%$ in hypertensive subjects and $30 \%, 50 \%$ and $20 \%$ in control group respectively, with significant higher frequency of DD allele and non significant difference of ID and II alleles in hypertensive patients as compared to the control group $(\mathrm{p}<0.05, \mathrm{p}>0.05$ and $\mathrm{p}>0.05$, respecti vely) ( table 2 ). Systolic blood pressure showed significant increase in DD patients (mean \pm SD $169.6 \pm 9.6 \mathrm{mmHg}$ ) as compared to ID $(160 \pm 3.6 \mathrm{mmHg}$; $\mathrm{p}<0.001$ )and II patients (mean \pm SD $157.8 \pm 4.6 \mathrm{mmHg} ; \mathrm{p}<0.01$ ), while there was non significant difference in systolic blood pressure between ID and II patients ( $>0.05)$ (tables 3 and 4 ). Diastolic blood pressure also showed significant increase in DD (106.4 \pm 7.9 $\mathrm{mmHg}$ ) patients as compared to ID $(99.6 \pm 3.9 \mathrm{mmHg} ; \mathrm{p}<0.001)$ patients and 
II $\quad(106.4 \pm 7.9 \mathrm{mmHg} ; \mathrm{p}<0.001)$ patients, while there was non significant difference in diastolic blood pressure between ID and II patients ( $>>0.05$, tables 3 and 4). Serum cholesterol showed non significant increase in DD patients (mean \pm SD $251.6 \pm 38.1 \mathrm{mg} / \mathrm{dl}$ ) as compared to ID (mean \pm SD 234 $\pm 38.2 \mathrm{mg} / \mathrm{dl} ; \mathrm{p}>0.05)$ and significant increase as compared to II (mean \pm SD $203.8 \pm 12.3 \mathrm{mg} / \mathrm{dl} ; \mathrm{p}<0.001)$. Also, there was significant increase in serum cholesterol in ID patients as compared to II patients $(\mathrm{p}<0.01)$. The results of serum triglycerides (mean \pm SD $122.4 \pm$
$32.6,108.3 \pm 27.4$ and $105.7 \pm 38.8 \mathrm{mg} / \mathrm{dl})$ and HDL-C $(45.1 \pm 4.8,45.8 \pm 5.9$ and $45.2 \pm 6 \mathrm{mg} / \mathrm{dl}$ ) showed non significant differences between the 3 genotypes DD,ID and II respectively . LDL-C showed non significant increase in DD patients (mean \pm SD $182.4 \pm 41.9 \mathrm{mg} / \mathrm{dl}$ ) as compared to ID ( mean \pm SD $167.7 \pm 38.7 \quad \mathrm{mg} / \mathrm{dl} ; \quad \mathrm{p}>0.05) \quad$ and significant increase as compared to II patients (mean $\pm \mathrm{SD} 133.9 \pm 9.6 \mathrm{mg} / \mathrm{dl}$; $\mathrm{p}<0.001)$ and also, LDL-C was significantly increased in ID patients as compared to II patients $(\mathrm{p}<0.001)($ tables 3 and 4).

Table(1): The results (mean \pm SD) of systolic and diastolic blood pressure, serum cholesterol , triglycerides, HDL-C and LDL-C in hypertensive patients as compared to the control group.

\begin{tabular}{|l|l|l|l|}
\hline & $\begin{array}{l}\text { Patients } \\
(\mathrm{n}=100)\end{array}$ & $\begin{array}{l}\text { Control } \\
(\mathrm{n}=70)\end{array}$ & P value \\
\hline Systolic B.P (mmHg) & $163.8 \pm 8.5$ & $117.4 \pm 5.1$ & $<0.001$ \\
Diastolic B.P(mmHg) & $102.2 \pm 5.1$ & $76.4 \pm 4.4$ & $<0.001$ \\
Cholesterol (mg/dl) & $237.4 \pm 38.9$ & $174.4 \pm 17.3$ & $<0.001$ \\
Triglycerides (mg/dl) & $113.9 \pm 32.1$ & $109.4 \pm 18.7$ & $>0.05$ \\
HDL-C (mg/dl) & $45.4 \pm 5.5$ & $50.1 \pm 3.9$ & $<0.001$ \\
LDL-C (mg/dl) & $169.3 \pm 39.8$ & $102.3 \pm 17.4$ & $<0.001$ \\
\hline
\end{tabular}

$\mathrm{P}<0.001=$ significant.

$\mathrm{P}>0.05=$ non significant.

Table (2): Frequencies of ACE genotypes in patients and control group.

\begin{tabular}{|c|c|c|c|}
\hline 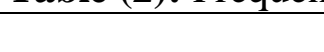 & DD & ID & II \\
\hline $\begin{array}{l}\text {-Hypertensive patients } \\
(\mathrm{n}=100) \text { : } \\
\quad \text { Number and }(\%)\end{array}$ & $42(42 \%)$ & $(44 \%)$ & $14(14 \%)$ \\
\hline $\begin{array}{c}\text {-Control group }(\mathrm{n}=70) \text { : } \\
\text { Number and }(\%) \\
\mathrm{p}\end{array}$ & $\begin{array}{l}21(30 \%) \\
<0.05\end{array}$ & $\begin{array}{l}35(50 \%) \\
>0.05\end{array}$ & $\begin{array}{l}14(20 \%) \\
>0.05\end{array}$ \\
\hline
\end{tabular}

$\mathrm{P}<0.05=$ significant

Table(3): Charecteristics and results (mean \pm SD) biochemical parameters among ACE genotyoes in patients $(\mathrm{n}=100)$

\begin{tabular}{|l|l|l|l|}
\hline & $\begin{array}{l}\mathrm{DD} \\
(\mathrm{n}=42)\end{array}$ & $\begin{array}{l}\text { ID } \\
(\mathrm{n}=44)\end{array}$ & $\begin{array}{l}\text { II } \\
(\mathrm{n}=14)\end{array}$ \\
\hline $\begin{array}{l}\text {-Age (years) } \\
\text {-Sex: male } \\
\quad \text { female }\end{array}$ & $40.7 \pm 3.9$ & $44.1 \pm 4.6$ & $44 \pm 4.1$ \\
-Blood pressure(mmHg): & 18 & 26 & 4 \\
Systolic & 24 & 18 & 10 \\
Diastolic & $169.6 \pm 9.6$ & $160 \pm 3.6$ & \\
-S. cholestrol (mg/dl) & $106.4 \pm 7.9$ & $99.6 \pm 3.9$ & $157.8 \pm 4.6$ \\
-S.triglycerides (mg/dl) & $251.6 \pm 38.1$ & $234 \pm 38.2$ & $97.8 \pm 2.5$ \\
-HDL-C (mg/dl) & $122.4 \pm 32.6$ & $108.3 \pm 27.4$ & $203.8 \pm 12.3$ \\
-LDL-C (mg/dl) & $45.1 \pm 4.8$ & $45.8 \pm 5.9$ & $105.7 \pm 38.8$ \\
\hline
\end{tabular}


Table (4):Comparison of the results of blood pressure, serum cholesterol, triglycerides, HDL-C and LDL-C between ACE genotypes.

\begin{tabular}{|l|l|l|l|}
\hline & DD vs. ID & DD vs. II & ID vs.II \\
\hline Blood pressure(mmHg): & & & \\
$\quad$-Systolic & $\mathrm{p}<0.01$ & $\mathrm{p}<0.01$ & $\mathrm{p}>0.05$ \\
-Diastolic & $\mathrm{p}<0.001$ & $\mathrm{p}<0.001$ & $\mathrm{p}>0.05$ \\
S.cholesterol $(\mathrm{mg} / \mathrm{dl})$ & $\mathrm{p}>0.05$ & $\mathrm{p}<0.001$ & $\mathrm{p}<0.01$ \\
S.triglycerides $(\mathrm{mg} / \mathrm{dl})$ & $\mathrm{p}>0.05$ & $\mathrm{p}>0.05$ & $>0.05$ \\
HDL-C $(\mathrm{mg} / \mathrm{dl})$ & $\mathrm{p}>0.05$ & $\mathrm{p}>0.05$ & $>0.05$ \\
LDL-C $(\mathrm{mg} / \mathrm{dl})$ & $\mathrm{p}>0.05$ & $\mathrm{p}<0.001$ & $<0.001$ \\
\hline
\end{tabular}

$\mathrm{P}<0.05=$ significant $\quad \mathrm{p}>0.05=$ non significant.

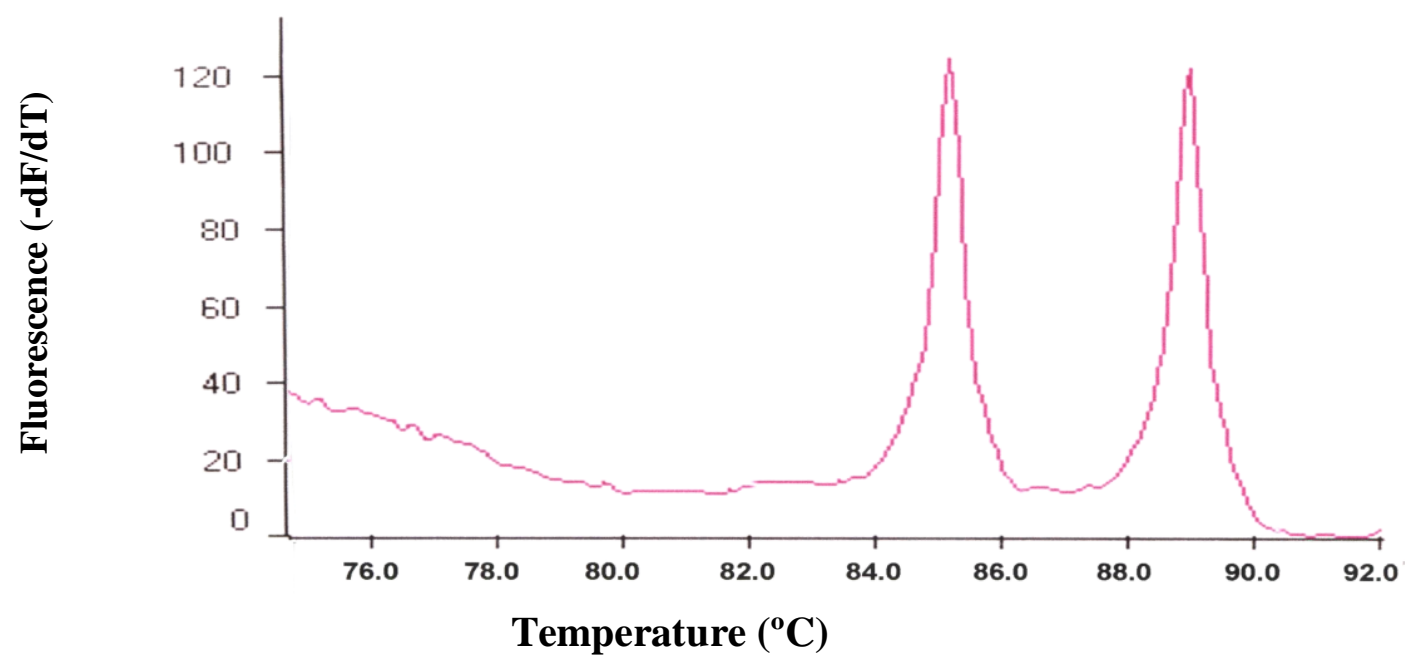

Figure (1): Melting curve of PCR product of ACE gene showing two peaks at $85.5^{\circ} \mathrm{C}$ (I allele) and at $89^{\circ} \mathrm{C}$ ( D allele).

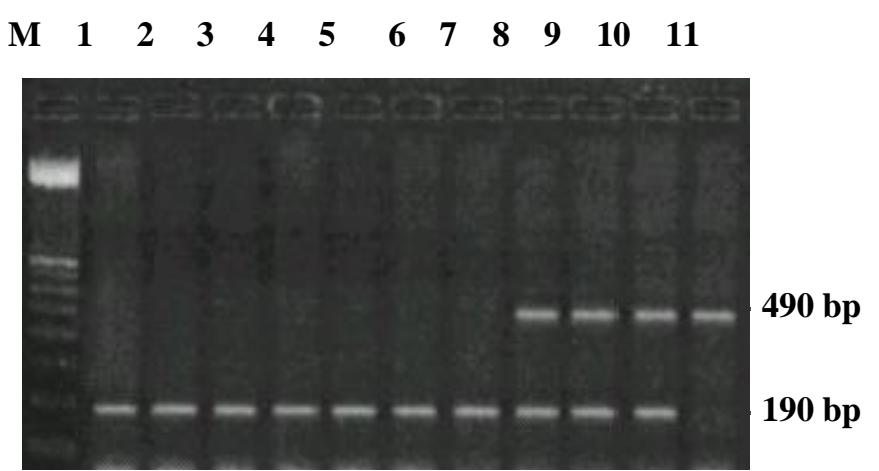

Figure (2): Agarose gel electrophoresis of PCR products of angiotensin-converting enzyme gene. M: marker, lanes 1-7: homozygous DD cases, lanes 8-10 hetrozygous ID and lane 11: homozygous II case.

\section{Discussion :}

Essential hypertension (EH) refers to a lasting increase in blood pressure with underlying heterogenous genetic components that remain unknown (Staessen et al.,2002). There is a strong evidence to support the idea that the 
renin-angiotensin system plays an important role in the pathogenesis of essential hypertension and its complic ations( Gesang et al.,2002). Studies have shown that the insertion/deletion polymorphism in interon 16 of the ACE gene accounts for approximately half the variance in ACE plasma level (Rigat et al., 1990).Consequently, ACE has been postulated as candidate gene of hypertension . However, studies in various groups have shown conflicting evidence of an association between ACE I/D polymorphism and essential hypertesion (O’Donnell et al., 1998 and Higaki et al.,2000). The results of this study showed that the frequency of DD genotype was significantly higher in $\mathrm{EH}$ patients (42\%) as compared to the control group $\quad(30 \% ; \mathrm{p}<0.05)$. In agreement with our results those obtained by Qiu et al., (1999) who found that the frequency of homoz ygous allele DD was significantly higher in a Chinese group with essential hypertension $(51.9 \%)$ than in healthy group $(35.7 \%$; $\mathrm{p}<0.01)$. Also, SunderPlassmann et al., (2002) reported the frequency of DD genotype to be significantly higher in a group of hypertensive patients $(38.5 \%)$ as compared to normotensive group (28\% $; \mathrm{p}<0.05)$. A large population based study has shown a linkage between the ACE locus and hypertension, and an association between ACE/ID polymor phism and essential hypertesion (Fomage et al.,1999). In the present study there was association of DD genotype with hypertension as both systolic and diastolic blood pressure were significantly higher in DD patients as compared to ID and II genotypes. In agreement with our results those obtained by Liu et al, (2000) and Morshed et al.,(2002), who found higher systolic and diastolic blood pressure in patients with DD genotype as compared to those with ID and II genotypes.

On the other hand, Chowdhury et al.,(1998) found no association between DD genotype and hypertension in a group of Pangladish patients with hypertension. Also, Matsubara et al., (2002) reported lack of association between ACE I/D polymorphism and hypertension. The causes of these discrepancies are multiple. The most important cause is that hypertension is polygenic disorder. Racial and environmental factors may be responsible causes. The sample size is other factor, as larger population should be studied. The use of different laboratory techniques may be other factor (Tsai et al., 2002).

It has been suggested that ACE I/D polymorphism might modulate the lipoprotein/ lipid profile and its response to fibrate thrapy (Bosse et al.,2002). The results of this study showed significant increase in serum cholesterol ,HDL-C and LDL-C in hypertensive patients as compared to control group $(\mathrm{p}<0.001)$. On the other hand serum triglycerides showed non significant change between patients and control group $(\mathrm{p}>0.05)$. Higaki et al.,(2000) found significant increase in serum cholesterol, HDL-C and triglyc erides in a group of Japanese patients with essential hypertension. When comparing the ACE genotypes, our results showed significant increase in serum cholesterol and LDL-C in DD patients as compared to II patients but not to ID patients. They also showed significant increase in ID patients as compared to II. On the other hand, the results of serum triglycerides and HDL$\mathrm{C}$ showed non significant difference between the three genotypes of ACE $(p>0.05)$. The ACE DD genotype has been shown to be associated with increased plasma concentration of ACE, 
which results in enhanced convertion of angitensin I to II , which stimulate cholesterol biosynthesis in macrophage (Batalla et al.,2000 ). A previous study reported the lack of association between ACE gene polymorphism and serum cholesterol, HDL-C, LDL-C and triglycerides in a group of patients with hypertension (Pereira et al., 2002). On the other hand, Kawamoto et al.,( 2002) found significant association between DD genotype and total cholesterol in a group of patients with hypertension and carotid atherosclerosis.

\section{Conclusion:}

ACE gene DD genotype showed significantly higher frequency in patients with essential hypertension and was associated with higher blood pressure as compared to the other genotypes ID and II . Also, DD genotype was associated with higher serum cholesterol and LDL-C as compared to II genotype in patients with essential hypertension . This variation in ACE gene may contribute to the development and severity of hypert ension and may help in selection of anti-hypertensive drugs.

\section{References:}

1. Batalla A., Alvarez R., ReueroJ.R., Hevia S., Alvarez V., Coetina A., Gonzalez P. Celada M., Medina A. and Coto E. (2000): Synergestic effect between Apolipoprotein $\mathrm{E}$ and angiotensin gene polymorphism in the risk for early myocardial infarction. Clin. Chemist., 46:1910-1915.

2. Baudin B.(2002): New aspects on angiotensin-converting enzyme: from gene to disease. Clin. Chem. Lab. Med.; 40:256-265.

3. Bosse Y., Vohl M.C., Dumont M. and Brochu M. (2002): Infuence of the angiotensin-converting enzyme gene insertion/deletion polymorphism on lipoprotein/lipid response to gemfibr ozil. Clin.Genent.; 62:45-52.
4. Caulfield M., Munroe P., Pemborke J., Samani N., Dominiczak A., Brown M., Benjamin N.,Webester $J$ and Ratcliffe P.( 2002): Genome-wide mapping of human loci for essential hypertension.Lancet;361:2118-2112.

5. Chowdhury A.H., Zaman M.M., Haque K.M., Rouf M.A., Shah A.T.and Tanaka H. (1998): Association of angiotensin-conve -rting enzyme (ACE) gene polymor -phism with hypertension in a Bangladish population. Bangladesh. Med. Res. Coun. Bull.;24:55-59.

6. Fomage M., Amos C.I. and Kardia S. (1999): Variation in the region of theangiotensin-converting enzyme gene influences interindi -vidual differences in blood pressure levels inyoung white males. Circulation ; 97:1773-1779.

7. Gesang L., Liu G., Cen W., Qui C.,Zhuoma C., Zhunag $L$ and Ren D. (2002):Angiotensin-converting enzyme gene polymorphism and its association with essential hyperte -nsion in Tibetian population. Hypertens. Res.; 25:481-484.

8. Higaki J., Baba S., Katsuya T. and Mannami T. (2000): Deletion allele of enzyme gene increase risk of essential hypertension in Japa -nese men. Circulation; 101: 2060-2068.

9. Kato N. (2002): Genetic analysis in human hypertension. Hypertens. Res.; 25: 319-325.

10. -Kawamoto R., Kohara K., Tabara Y. and Miki T. (2002): An interaction between systolic blood pressuree and angiotensin-converting enzyme gene polymorphism on carotid atheroscl erosis. Hypertens. Res.; 25:875-879.

11. Lasocki S.,Vuillaumier-Barrot S., Henrion D., Benessiano J. and Desmonts J. (2002) :Involvement of rennin-angiotensin system in pressureflow relationship. Anesthsiology; 95: 261-263.

12. Lifton R.P., Charavi A.G. and Geller D.S. (2001): Molecular mechanisms of human hypertension. Cell; 104: 5445556.

13. Lin M., Tseng C. H., Tseng C.C. Huang C. Chong C. and Tseng 
C.P.(2001): Real-time PCR for rapid genotyping of angiotensin-converting enzyme insertion/dele -tion polymorp hism. Clin. Biochem.; 34:661-666.

14. Liu Q., Lei H. and Wang X. (2000) :The relationship of angiotensinconverting enzyme gene to essential hypertension and drug treatment in Chonging. Chinese J. Prevent. Med.; 17:340- 342 .

15. -Matsubara M. (2000): Genetic determination of human essential hypertension. Tohoko J. Exp. Med.; 192:19-33.

16. Matsubara M., Suzuki M., Fujiwara T., Kikuya m., Metoki H., Micimata M., Araki T., Kazama I., Satoh T and Hashimoto J. (2002): Angiotensinconverting enzyme I/D polym -orphism and hypertesion: The Ohasama study. J.Hypertens.; 20:1121-1126.

17. Montgomery H., Brull D. and Humpheries S.E. (2002): Analysis of gene-environment interactions by "stressing- the- genotype" studies: the giotesin -converting enzyme and exercise-induced left ventricular hypertrophy as an example. Ital. Heart.J. ; 3: 10-14.

18. Morshed M., KhanH. And Akhteruzzaman S. (2002): Associ ation between angiotensin I-converting enzyme gene polymor -phism and hypertension in selected individuals of the Bangladeshi population. J. Biochem. Mol. Biol. ; 31:251-255.

19. O'Donnell C.J., Lindpaitner K. and Larson M.G. ( 1998): Evidence for association and genetic linkage of the angiotensin-converting enzyme locus with hypertension and blood pressure in men but not in women in the Framingham Heart Study. Circulation; 97:1766-1772.

20. Pereira A.C., Mota G.F., Cuha R.S., Herbenhoff F.L., Mill J. G. and Krieger J.E. (2002): Angiot -ensin 235T allele "dosage" is asso -ciated with blood pressure pheno -types. Hypertension; 41:25-30.
21. Rigat B., Hurbert C., Alhence-Gelas F., Cambien F., Corvol P. and Soubrier F. (1990) : An insertion/ deletion polymorphism in the angiote nsin I-converting enzyme gene accoun ting for half the varience of serum enzyme levels. J. Clin. Invest.; 86:1343-1346.

22. Rigat B., Hurbert C., Corvol P. and Soubrier F. (1992): PCR detection of the insertion/deletion polymorphism of the human angiotensin-converting enzyme gene (DCPI) (dipeptidyl carbo -xypeptidase I) . Nucleic Acids Res.; 20:1433.

23. Staessen J.A., Wang G., Bianchi G. and Birkenhar W.H. (2002): Essential hypertension. Lancet, 361:1629-1638.

24. Sunder-Plassmann G., Kittler H., Eberie C., Hirschl M., Woisetsclager C., Derhaschnig U., Laggner A.N., Horl W. and Fodinger $M$. (2002):Angiotensin-converting enzyme DD genotype is associated with hypertensive crisis. Crit.Care Med.; 30: 2236- 2241.

25. Tamaki S., Nakamura Y., Tsujita Y., Nozaki A., Amamoto K., and Kita Y.(2002): Polymorphism of the angiotnsin converting enzyme gene and blood pressure in Japanese general population ( the Shigaraki study). Hypertens.Res.; 25:843-851.

26. Tsai C., Fallin D., Chiang F., Hwang J., Lai L., Hsu K., Tseng C. , Liau C. and Tseng Y. (2002): Angiotensinogen gene haplotype and hypertension interaction with ACE gene I allele. Hypertension;41: 9-15.

27. Qiu C., Lu Y. Hu A., Guo Z. and Song C (1999): Deletion polymo rphism in the angiotensin converting enzyme gene associated with essential hypertension in Hans Chinese population. Chinese J. Prevent.Med.; 20:133-137.

28. Wilhelm J., Hahn M. and Pingoud A. (2000): Influence of DNA target melting behavior on real-time PCR quantification. Clin. Chem.; 46:17381743. 


\section{التباين فى جين الانزيم المحول للأنجيوتنسين فى مرضى ضغط الام

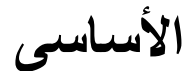 \\ ماجدة ابراهيم محمد المهدى و منى محمد مرسىى الاسيلى}

أقسام الباتولوجيا الاكلينيكية والباطنة العامة* كلية الطب (بنات) جامعة الأزهر هر.

حاول عدد من الأبحاث الجينية أن يوضح علاقة التباين فى جين الانزيم المحول

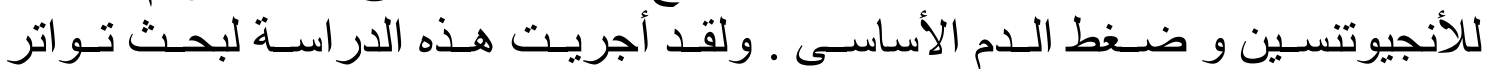

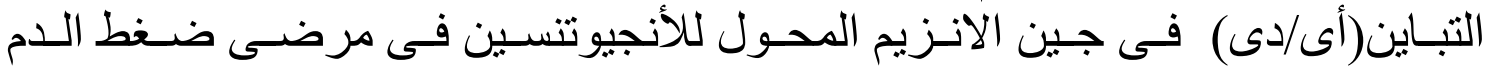

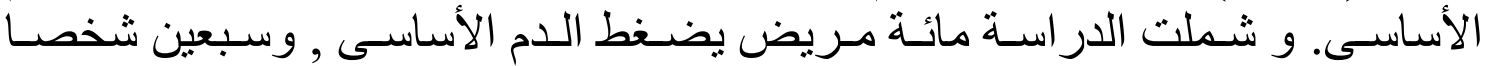

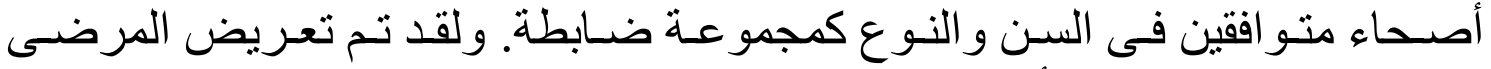

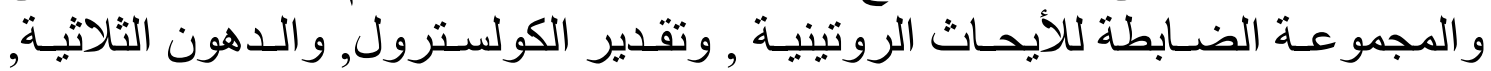

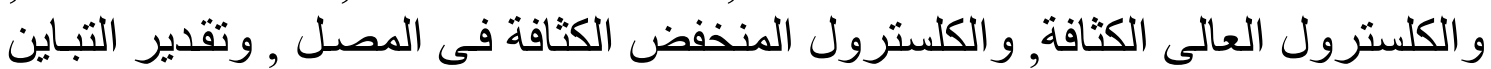

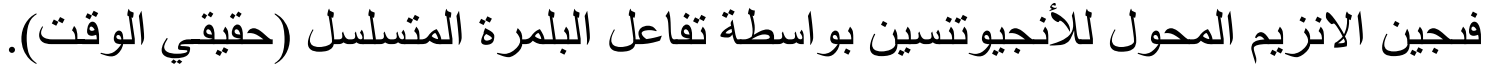

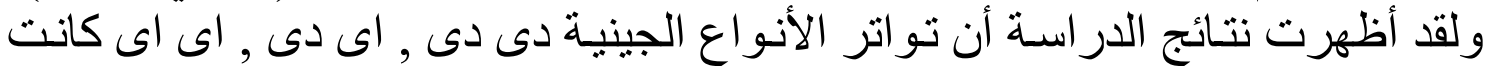

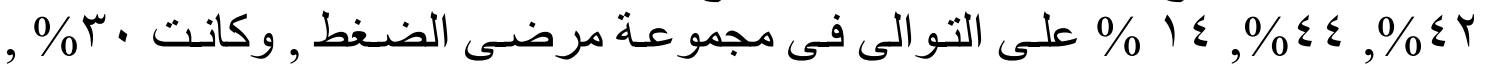

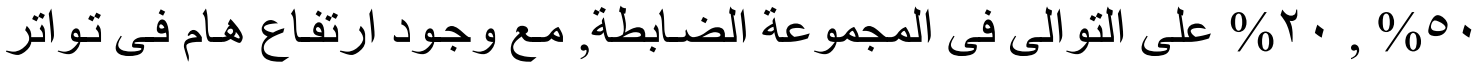

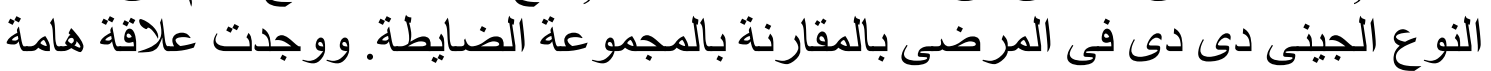

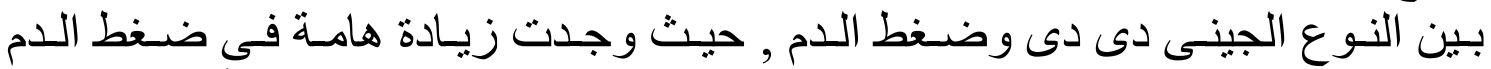

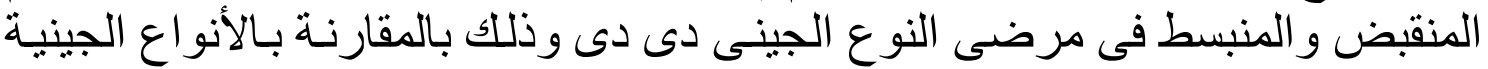

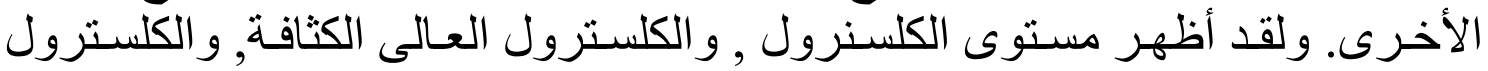

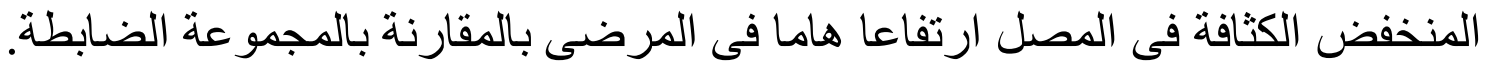

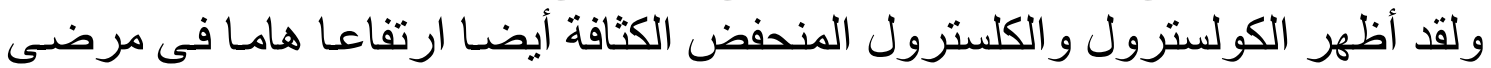

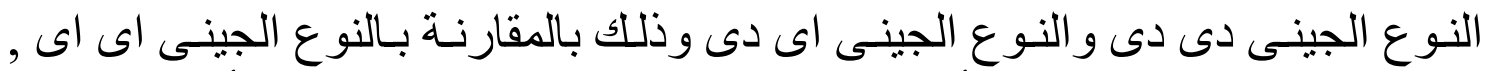

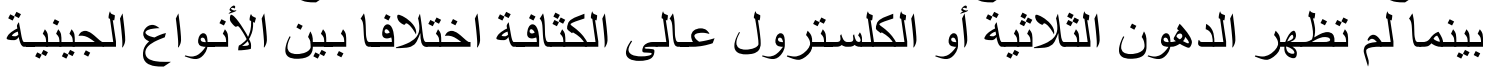

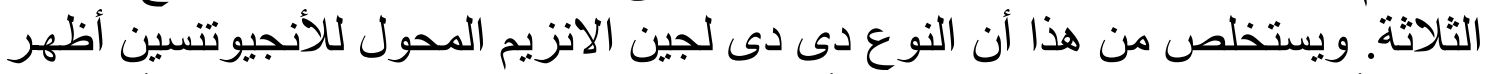

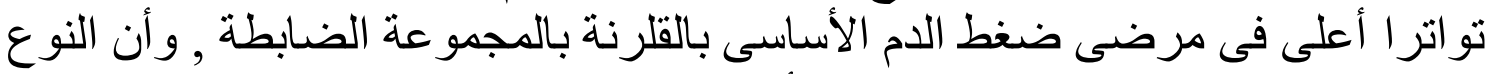

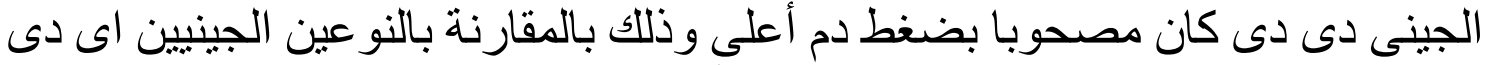

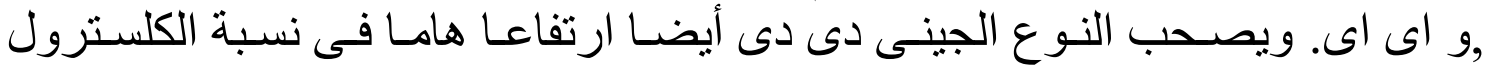

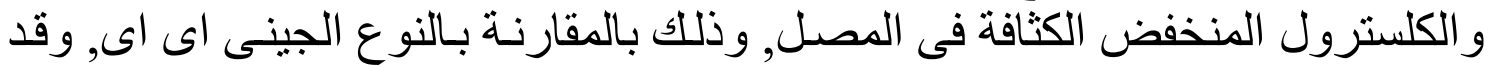

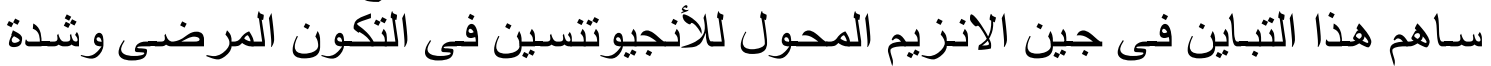

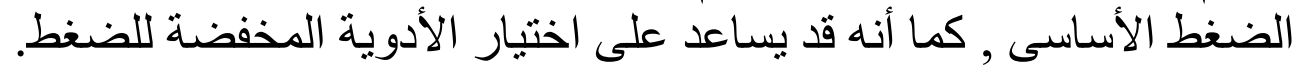

